\title{
INFLUENGE OF BOVINE DIABETOGENIC PEPTIDE, GROWTH HORMONE, AND PROLACTIN ON TISSUE GLYCOGEN, LIVER FAT, AND LIVER WATER OF FASTING RATS
}

\author{
GENE F. TUTWILER
}

Departments of Biological Chemistry and Internal Medicine (Division of Endocrinology and Metabolism and the Metabolism Research Unit), University of Michigan Medical School, Ann Arbor, Michigan 48 ro4, U.S.A.

(Received 29 June, 1970)

\begin{abstract}
I. Bovine diabetogenic peptide, growth hormone, and prolactin were compared with respect to their effects on tissue glycogen, liver fat, and liver water in fasting rats.

2. Bovine diabetogenic peptide increases liver size, liver glycogen, liver water, and total liver lipids.

3. Bovine diabetogenic peptide, in contrast to growth hormone and prolactin, does not increase muscle glycogen levels.
\end{abstract}

IN recent work from this laboratory (Louis, Conn, and Minick, 1963; Louis and Conn, $1969 \mathrm{a}, \mathrm{b})$, the isolation of an insulin antagonist from the urine of patients with lipoatrophic diabetes and from proteinuric diabetic patients without lipoatrophy has been reported. It was also demonstrated that a similar substance can be isolated from bovine, ovine, and porcine adenohypophysis (Louis, Conn, and Minick, 1966; Louis and Conn, 1968). The substance is a polypeptide which, when administered to either dog or man, exhibits diabetogenic and anti-insulin effects. The bovine substance is not growthpromoting and maintains muscle glycogen in fasting hypophysectomized rats (Tutwiler and Louis, 197r). The diabetogenic and glycostatic effects are similar to those previously elucidated for the growth hormone (BGH) and prolactin. The present report represents an attempt to delinate further biological differences between bovine diabetogenic peptide, growth hormone, and prolactin.

\section{MATERIALS AND METHODS}

Male Sprague-Dawley rats, $38-40$ days of age, were fasted for 24 hours; on the second day of fasting, $4.0 \mathrm{mg}$. of bovine diabetogenic peptide, growth hormone, or prolactin in 3 divided doses at 2-hour intervals were administered intraperitoneally. Control animals were given either saline or $4 \mathrm{mg}$. bovine serum albumin (BSA) in a similar manner.

The bovine diabetogenic peptide was prepared and dissolved by a procedure prescribed previously (Louis and others, I966). BGH (NIH-GH$\mathrm{B}_{8}$ ) was dissolved in 0.9 per cent $\mathrm{NaCl}$ with the addition of a small amount of $0.1 \mathcal{N} \mathrm{NaOH}$. Bovine prolactin (NIH-P-BI) and BSA were dissolved on 0.9 per cent $\mathrm{NaCl}$.

Two hours after the last injection the animals were sacrificed by decapitation. The whole liver, heart, diaphragm, and gastrocnemius muscle were removed, weighed, and frozen. Liver tissue from each rat was divided into 3 parts, weighed, and used respectively for total lipid, glycogen, and water determination. The liver tissue for water determination was placed in a tared glass tube and dried to constant weight in vacuo. The difference in weight beforc and after drying was taken as the water content. The isolation and hydrolysis of glycogen from the various tissues were carried out by the procedure of Zarrow, Yockin, and 
McCarthy (1964). Glucose determinations on these hydrolysates were measured by the SomoygiNelson procedure (Somogyi, 1952). Liver total lipids were determined by a slight modification of the method of Folch, Lees, and Stanley (1957).

\section{RESULTS AND DISCUSSION}

The changes in liver composition of fasted rats after treatment with bovine diabetogenic water content is significantly increased in the diabetogenic peptide treated rats. A somewhat higher fat content is also seen in diabetogenic peptide or BGH treated rats. The earlier experiments of Best and Campbell (1938) established the fact that certain anterior pituitary extracts produce a rapid increase in size and an intense fatty infiltration

Table I.-Effect of Bovine Diabetogenic Peptrde, Growth Hormone, and Prot.actin on the Liver Composition of FAsTED RATs*

\begin{tabular}{|c|c|c|c|c|c|c|}
\hline \multirow[b]{2}{*}{$\begin{array}{l}\text { HORMONE } \\
\text { INJECTED }\end{array}$} & \multirow[b]{2}{*}{$\begin{array}{l}\text { No. of } \\
\text { RAts }\end{array}$} & \multirow[b]{2}{*}{$\begin{array}{c}\text { BODX- } \\
\text { WEIGHT } \\
\text { (g.) }\end{array}$} & \multirow[b]{2}{*}{$\begin{array}{l}\text { LIVER Size } \\
\text { (g. per } 100 \mathrm{~g} \text {. } \\
\text { body-weight) }\end{array}$} & \multicolumn{3}{|c|}{ Liver Composition } \\
\hline & & & & $\begin{array}{c}\text { Water } \\
\text { (per cent) }\end{array}$ & $\begin{array}{c}\text { Fat } \\
\text { (mg. per g. } \\
\text { dry weight) }\end{array}$ & $\begin{array}{c}\text { Glycogen } \\
\text { (mg. per 10o g. } \\
\text { wet weight) }\end{array}$ \\
\hline $\begin{array}{l}\text { Diabetogenic } \\
\text { peptide }\end{array}$ & 12 & $190-219$ & $\begin{array}{l}3.10 \pm 0.05 \\
P<0.001\end{array}$ & $\begin{array}{l}72 \cdot 6 \pm 0.5 \\
P<0.001\end{array}$ & $\begin{array}{l}165 \pm 3 \\
P<0 \cdot 001\end{array}$ & $\begin{array}{l}34^{2} \pm 3^{8} \\
P<0001\end{array}$ \\
\hline $\begin{array}{l}\text { Growth } \\
\text { hormone }\end{array}$ & 9 & $174-205$ & $\begin{array}{l}3.34 \pm 0.05 \\
P<0.001\end{array}$ & $\begin{array}{l}70.65 \pm 0.21 \\
P<0.05\end{array}$ & $\begin{array}{l}159 \pm 4 \\
P<0 \cdot 005\end{array}$ & $\begin{array}{l}281 \pm 5 \\
P<0.001\end{array}$ \\
\hline Prolactin & 8 & $16 x-203$ & $\begin{array}{l}3.0 \pm 0.04 \\
p<0.05\end{array}$ & $\begin{array}{l}69.7 \pm 0.4 \\
P<0.9\end{array}$ & $\begin{array}{l}142 \pm 2 \\
P<0 \cdot 7\end{array}$ & $\begin{array}{l}386 \pm 59 \\
P<0 \cdot 001\end{array}$ \\
\hline Saline & 15 & $160-205$ & $2 \cdot 80 \pm 0.57$ & $\begin{array}{c}70.4 \pm 0.1 \\
0.05<P<0.1\end{array}$ & $149 \pm 2$ & $7^{8} \pm 7$ \\
\hline BSA & 10 & $170-23^{\circ}$ & $\begin{array}{c}2.82 \pm 0.05 \\
0.8<P<0.9\end{array}$ & $69.7 \pm 0.4$ & $\begin{array}{l}144 \pm 3 \\
P>0.9\end{array}$ & $\begin{array}{c}86 \pm 13 \\
0.5<P<0.6\end{array}$ \\
\hline
\end{tabular}

* Results expressed as mean \pm S.E. $P$ computed from Student's $t$-test analysis.

Table II.--Effect of Bovine Diabetogenic Peptide, Growth Hormone, and Prolactin on Tissue Glycogen Levels of Fasted Rats

\begin{tabular}{|c|c|c|c|c|}
\hline \multirow{2}{*}{$\begin{array}{l}\text { HORMONE } \\
\text { INJECTED }\end{array}$} & \multirow{2}{*}{$\begin{array}{l}\text { No. of } \\
\text { Rats }\end{array}$} & \multicolumn{3}{|c|}{ Glycogen Content (mg. per loo g.) } \\
\hline & & Gastrocnemius & Cardiac Muscle & Diaphragm \\
\hline $\begin{array}{l}\text { Diabetogenic } \\
\text { peptide }\end{array}$ & 12 & $\begin{array}{l}165 \pm 9 \\
0.6<P<0.7\end{array}$ & $\begin{array}{l}225 \pm 15 \\
0.7<P<0.8\end{array}$ & $\begin{array}{l}\text { I } 15 \pm \text { to } \\
P<0.9\end{array}$ \\
\hline $\begin{array}{l}\text { Growth } \\
\text { hormone }\end{array}$ & 9 & $\begin{array}{l}25^{8} \pm 14 \\
P<0.001\end{array}$ & $\begin{array}{l}373 \pm 19 \\
P<0.001\end{array}$ & $\begin{array}{l}171 \pm 7 \\
P<0 \cdot 001\end{array}$ \\
\hline Prolactin & 8 & $\begin{array}{l}217 \pm 12 \\
P<0.02\end{array}$ & $\begin{array}{l}322 \pm 22 \\
P<0.02\end{array}$ & $\begin{array}{l}160 \pm 7 \\
P<0.001\end{array}$ \\
\hline Saline & 15 & $\begin{array}{l}187 \pm 7 \\
0.2<P<0.3\end{array}$ & $\begin{array}{l}205 \pm 10 \\
0.3<P<0.4\end{array}$ & $\begin{array}{l}108 \pm 5 \\
0.2<P<0.3\end{array}$ \\
\hline BSA & Io & $171 \pm 11$ & $235 \pm 9$ & I $16 \pm 7$ \\
\hline
\end{tabular}

peptide, growth hormone, and prolactin are summarized in Table $I$. It is evident that the livers of diabetogenic-, growth-, or prolactintreated rats have a higher wet weight and glycogen content than the control rats. Water content of liver tissue is not significantly altered by BGH or prolactin treatment; however, liver of the liver in fasting rats. Li, Simpson, and Evans (1949) observed an increase in fat content of the liver when growth hormone was administered to fasting normal and hypophysectomized rats. The present experiments reconfirm the ability of $\mathrm{BGH}$ to increase liver fat in fasting normal rats. The 
present study shows that the diabetogenic peptide from bovine adenohypophysis also possesses this property. Since under these circumstances the accumulation of lipid in the liver is an indirect measure of fatty acid mobilization from adipose tissue, it is likely that the diabetogenic peptide possesses a lipid-mobilizing effect similar to BGH. This possibility is now being tested.

Muscle glycogen levels following the various procedures are shown in Table II. BGH- and prolactin-treated animals have higher muscle glycogen than the controls. The diabetogenic peptide exhibits no effect on muscle glycogen. Russell (1955) described the growth-hormone-stimulated increase in cardiac glycogen in fasting intact rats as a growth property. The two known growth-promoting peptides, BGH and prolactin, have here again been shown to increase cardiac glycogen while the nongrowth-promoting diabetogenic peptide does not exert this effect.

\section{REFERENCES}

Best, C. H., and Camprell, J. (1938), 'The effect of anterior pituitary extracts on the liver fat of various animals', $\mathcal{f}$. Physiol., Lond., $92,9 \mathrm{r}-1 \mathrm{l}$.

Folch, J., Lees, M., and Stanley, G. H. S. (1957), "A simple method for the isolation and purification of total lipides from animal tissues', 7. biol. Chem., 226, 497-509.

LI, C. H., Simpson, M. E., and Evans, H. M. (1949), "The influence of growth and adreno- corticotropic hormones on the fat content of the liver', Archs Biochem., 23, 51-54.

Lours, L. H., and ConN, J. W. (1968), 'A diabetogenic polypeptide from hog and sheep adenohypophysis similar to that found in lipoatrophic diabetes', Metabolism, 17, 475-484.

Lours, L. H., and Cons, J. W. (rg6ga), 'Lipoatrophic diabetes: An improved procedure for the isolation and purification of a diabetogenic peptide from urine ', Metabolism, 18, 545-555.

Lous, L. H., and Cons, J. W. (1969b), "A urinary diabetogenic peptide in proteinuric diabetic patients , Metabolism, 18, 556-563.

Lours, L. H., ConN, J. W., and Minick, M. C. $(1963)$, 'Isolation and characterization of an insulin antagonist from urine ', Metabolism, 12, $867-886$.

Lours, L. H., Conn, J. W., and Minick, M. C. (1966), "A diabetogenic polypeptide from bovine adenohypophysis similar to that excreted in lipoatrophic diabetes ', Metabolism, r5, 309324 .

Russer.., J. A. (1955), in The Hypophyseal Growth Hormone, Nature and Actions (ed. Smrrt, R. W., GakBLER, O. H., and LoNG, C. N. H.), pp. 2021. New York: McGraw-Hill.

Somogrt, M. (1952), 'Notes on sugar determination ', 7. biol. Chem., 195, 19-23.

TUTwiler, G. F., and Lours, L. H. (1971), 'Glycostatic effect of a diabetogenic nongrowth promoting pituitary polypeptide , Int. $^{\prime}$. Biochem., 2, 319-323.

Zarrow, M. X., Yockin, J. M., and McCarthy, J. L. $(1964)$, Experimental Endocrinology-A Sourcebook of Basic Techniques, p. 217. New York: Academic Press.

Key Word Index: Bovine diabetogenic peptide, growth hormone and prolactin, comparative effects in vivo, glycogenic, liver fat increase. 